
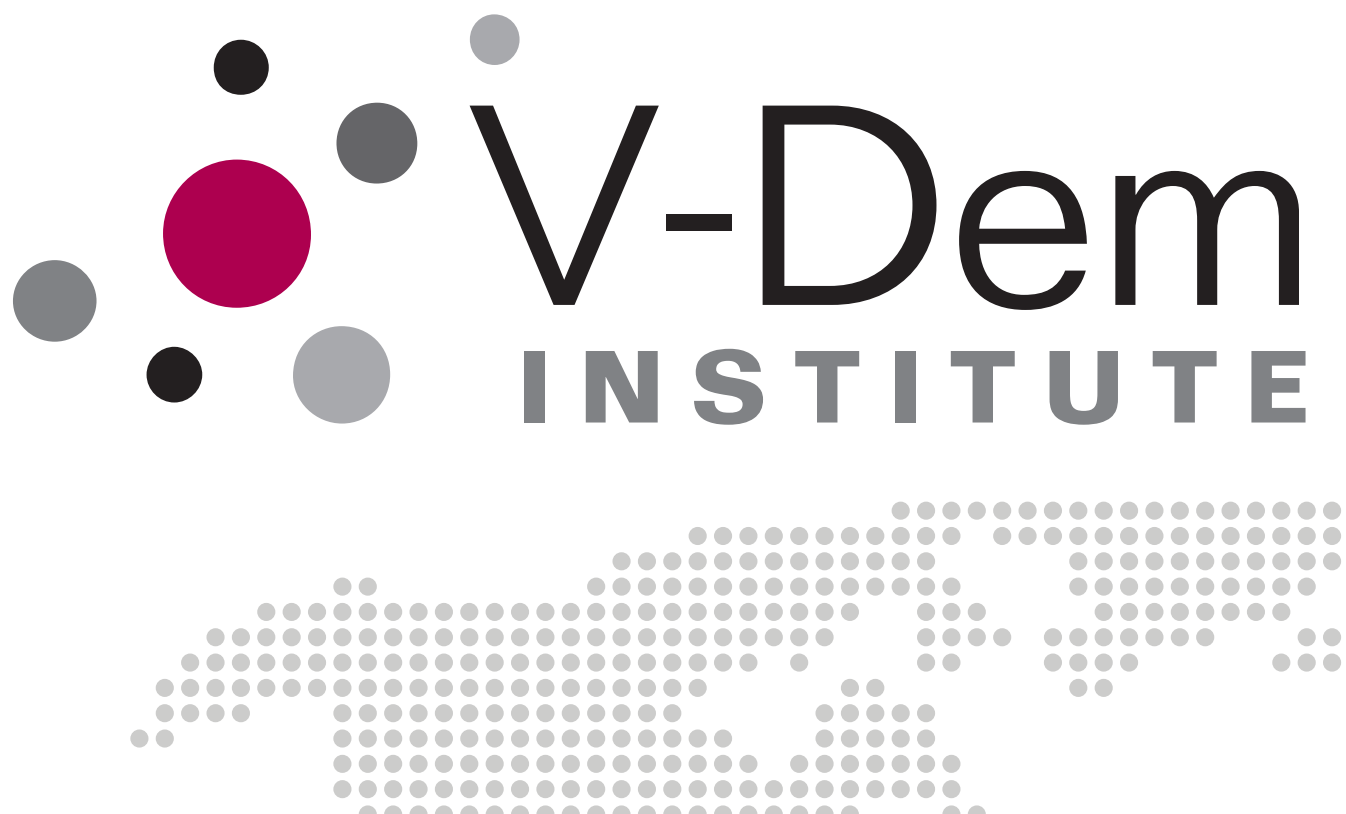

\title{
Autocracy and Variation in Economic Development Outcomes
}

Carl Henrik Knutsen

$$
\begin{array}{rrr}
0000 \\
000000
\end{array}
$$
$1000000000000000 \mathrm{c}$ 0000 00000000000000

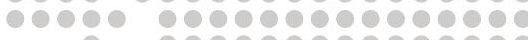
100

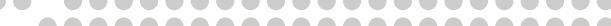


rebere

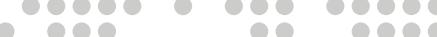

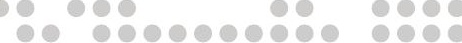

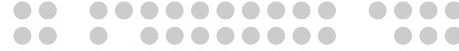

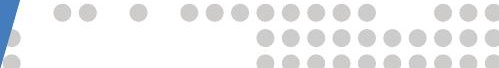
000000000900900000

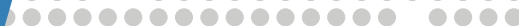
6000000000000000

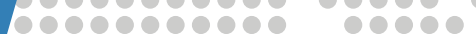

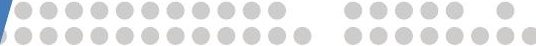
1960000000000

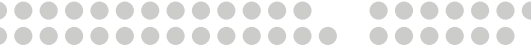

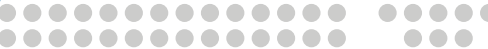

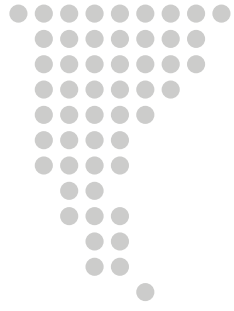

November 2018

\section{Working Paper}

SERIES 2018:80 
Varieties of Democracy (V-Dem) is a new approach to conceptualization and measurement of democracy. The headquarters - the V-Dem Institute - is based at the University of Gothenburg with 17 staff. The project includes a worldwide team with six Principal Investigators, 14 Project Managers, 30 Regional Managers, 170 Country Coordinators, Research Assistants, and 3,000 Country Experts. The V-Dem project is one of the largest ever social science research-oriented data collection programs.

Please address comments and/or queries for information to:

V-Dem Institute

Department of Political Science

University of Gothenburg

Sprängkullsgatan 19, PO Box 711

SE 40530 Gothenburg

Sweden

E-mail: contact@v-dem.net

V-Dem Working Papers are available in electronic format at www.v-dem.net.

Copyright (C) 2018 by authors. All rights reserved. 


\title{
Autocracy and Variation in Economic Development Outcomes*
}

\author{
Carl Henrik Knutsen \\ Professor \\ Department of Political Science, University of Oslo
}

* This research was funded by the Research Council Norway's Young Research Talent Grant, pnr240505. 


\section{Abstract}

I discuss and analyze the vast variation in development outcomes among autocracies, focusing on economic growth. I highlight plausible explanations of this variation pertaining to features of the leader, institutions, or the regime's support coalition. Next, by analyzing data from more than 180 polities and with time series extending back to 1789, I present descriptive patterns and tests corroborating that variation in growth - in the shorter and longer term, across and within countries - is higher among autocracies than democracies. Finally, I assess the explanations for why some autocracies have higher growth than others. This exercise suggests that single-party autocracies have higher growth than personalist regimes and monarchies. Higher degrees of party institutionalization also correlate positively with growth. I find several (surprising) negative and null results. Notably, neither stronger legislative constraints on the autocrat nor the size of an autocratic regime's support coalition correlate positively with growth. 


\section{Introduction}

One widespread notion in the study of comparative development is that "institutions matter". While the broader literature covers a plethora of plausible determinants, including geographic features (Gallup et al. 1999), access to particular natural resources (Pomeranz 2000), demographic developments (Clark 2007), and certain cultural and normative affinities (Landes 1998), "institutions" has come to be the dominant response by scholars trying to answer the question: "Why are some countries rich and others poor"?

Seminal studies on institutions and development in the 1990s focused mainly on economic institutions pertaining to stable private property rights and the enforcement of contracts (see, e.g., North 1990; Knack and Keefer 1995). Such institutions were considered as key factors not only for promoting investments in physical capital, but also for enhancing other "immediate determinants" of economic growth, including labor supply, human capital accumulation, and even technological change (Hall and Jones 1999).

Subsequent research turned towards investigating where such "good institutions" come from, highlighting historical and geographical determinants (e.g., Acemoglu et al. 2001; Engerman and Sokolof 2002). Another answer to the question of where good economic institutions - and, indeed, the tendency for some leaders to select growth-enhancing policies, more generally - come from, points towards a set of other (political) institutional features. How the political regime is organized and who holds power affect the incentives and capabilities of leaders to provide good economic institutions and pursue growth-enhancing policies. A particular focus has been placed on the democracy — autocracy distinction. Rodrik (2000), for example, labels democracy a "metainstitution" that influences the set-up and persistence of other institutions.

One influential such hypothesis is that democracy strengthens the protection of private property rights. Democratically elected incumbents need to be responsive to a broader set of citizens than autocrats do, and this increases the incentives to provide a system of broad-based property rights (e.g., Olson 1993; Bueno de Mesquita et al. 2003; Knutsen 2011a). In contrast, autocratic leaders, who often rely on narrow elite-groups for staying in power, may even have direct incentives to expropriate property from potential threats (e.g., Albertus and Menaldo 2012; Ansell and Samuels 2014). But, the list of economic institutions and policies that democracy might influence extends beyond property rights protection, including industrial-, fiscal-, monetary-, education-, and healthcare policies (e.g., Przeworski and Limongi 1993; Baum and Lake 2001; Doucouliagos and Ulubasoglu 2008; Knutsen 2012). Some channels point towards a positive indirect effect of democracy on growth, whereas others suggest a growth advantage for 
autocracies. In any case, there are strong theoretical reasons for believing that democracy may (indirectly) affect economic development outcomes.

Against this background of plausible theoretical arguments, the empirical literature on the aggregate relationship between democracy and economic growth is characterized by surprisingly mixed and non-robust results. The standard conclusion in this literature is that we do not know for sure whether or not democracy matters for growth (see, e.g., Clark et al. 2018, chapter 9), and that estimates depend on the sample, set of control variables, choice of democracy measure, and other specification issues (e.g. Doucouliagos and Ulubasoglu 2008). The same goes for other prominent development outcomes, such as infant mortality (Gerring et al. 2012) and education outcomes (Dahlum and Knutsen 2018).

Importantly, such bodies of mixed evidence do not imply that democracy is irrelevant for development. Returning to economic growth, more specifically, the early cross-country regression literature tended, more often than not, to find either negative or statistically insignificant results for democracy (Przeworski and Limongi 1993). Yet, this early literature suffered from several key methodological shortcomings. More recent studies that account for one or several of these shortcomings more often find a positive relationship between democracy and growth (see Knutsen 2012). For example, early studies tended to only include data from a subset of (economically successful) autocracies, whereas later studies have employed more comprehensive samples (Halperin et al. 2005). Also, the GDP data reported in autocracies may be systematically overreported (Martinez 2018), attenuating the true relationship between democracy and growth. Further, studies that adjust for democratization being endogenous to prior growth dynamics (Acemoglu et al. 2018), that do not over-control for channels through which democracy indirectly affects growth (Doucoliagos and Ulubasoglu 2008), or that account for the substantial time lag before the positive effect of democracy materializes (Gerring et al. 2005; Papaiouannou and Siourounis 2008), find clearer positive results.

Despite these important caveats, it is fair to say that literatures studying the (average) effect of democracy on various development outcomes often come to inconclusive or, at least, nonrobust, results. In contrast, a more consistent finding is that while there is substantial variation among relatively democratic regimes, the variation is especially high among relatively autocratic ones. ${ }^{1}$ As Jennifer Gandhi (2008: 3) notes, "[s]ome countries experience phenomenal rates of

\footnotetext{
1 To give a few examples of studies suggesting variation among democratic regimes, Persson and Tabellini (2006) suggest that form of government (presidentialism vs parliamentarism) matters for growth outcomes in new democracies, whereas Knutsen (2011b) finds that the electoral system matter for economic growth in a large sample of democracies. Further, Norris (2012) highlights that the relationship between democracy and economic development outcomes may be contingent on the level of state capacity (but, see, e.g., Hanson 2015), whereas Fukuyama (2014)
} 
economic growth while governed by dictatorship. The East Asian "tigers", such as Malaysia, Singapore, Taiwan, and South Korea all achieved growth rates of over ten percent under the thumb of dictators. Yet some of the worst economic disasters also occur under dictatorial regimes: both short-lived crises and long-term devastation resulting from years of neglect and theft, as in the case of Zaire under Mobutu Sese Seko.”

For example, Rodrik $(2000,2008)$ finds that democracies are less prone to experience high short-term volatility in growth, but also that the cross-sectional variance in growth is larger among autocracies than democracies. This finding is corroborated by several scholars, including Besley and Kudamatsu (2007), who show that the "tails" in the growth distribution are much fatter for autocratic observations than for democratic ones. Studying the time period between 1950 and 1990, Przeworski et al. (2000) present lists of so-called "growth miracles" and "growth disasters". Autocratic regimes dominate both lists. The finding on higher variance in autocratic development outcomes is not limited to growth. For example, Dahlum and Knutsen (2017) show that there is higher variation in education quality among autocracies than there is among democracies.

In this paper, I revisit the question of heterogeneity in growth performance among democracies and autocracies and address some factors that potentially underlie the vast variation among autocracies. To this end, I draw on the most comprehensive dataset on regime type and growth so far used in the literature. But, before proceeding, let me provide some clarifications: For the sake of convenience, I will often dichotomize regimes as "democratic" and "autocratic" in the ensuing discussion, even though I conceive of democracy-autocracy as a continuous dimension where regimes can be more or less democratic. Thus, "autocratic regime" is shorthand for "regime with relatively low degree of democracy". In the empirical part, I will specify thresholds for considering a country "democratic", but also use continuous measures of democracy. Next, regarding “economic development”, I focus on changes in GDP per capita, i.e., economic growth. Yet, I will employ different operationalizations to capture, for example, both short- and long-term growth.

In the remainder of this paper, I review extant arguments and empirical studies on select factors - focusing on political and institutional ones - that may generate variation in development outcomes among autocracies. Next, I present descriptive statistics on the variance in growth performance among autocracies as well as regression analysis on measures of variation in growth with regime type as the key independent variable. These analysis are conducted on new and extensive data material - covering 184 countries, with time series from 1789 to the present - and 
replicates the result that autocracies have systematically higher variance in economic growth than democracies. Thereafter, I focus the analysis on the subset of autocratic regimes and conduct tests on how several of the political and institutional factors highlighted in the literature review relate to GDP per capita growth.

\section{What explains variation in economic development among autocracies? A brief review of potential political and institutional determinants.}

The chief executive is one obvious place to start when considering variations in development outcomes among autocracies. Since decision-making power is more concentrated in autocracies than in democracies, the cognitive abilities, personal preferences and other features of the top leadership presumably matter more in the former. Theoretical work has addressed how variations in the personal preferences of leaders may induce systematic differences in policies (e.g., Wintrobe 1998), and there is a widespread notion in historical case-oriented work that leader identities matter. Fukuyama (2005), for instance, proposes that autocracies "as a group might do well if they could all be run by Lee Kwan Yew; given that they are as often run by a Mobutu or a Marcos, it is not surprising that [autocratic regimes] show much greater variance than democratic ones in terms of development outcomes" (p.37).

In a prominent study of leaders and economic growth, Jones and Olken (2005) - using a clever research design that considers natural deaths to leaders as exogenous shocks (thus mitigating the reverse causality issue that low growth may get leaders kicked out of office) -find indications that leader identities matter for growth in autocracies. More specifically, they "find evidence that the death of leaders in autocratic regimes leads to changes in growth while the death of leaders in democratic regimes does not. Moreover, among autocrats, leader effects appear more pronounced when leaders have fewer constraints on their power" (p. 837).

Yet features of the autocratic regime, also beyond the identity of the particular leader, may systematically influence development outcomes (as well as moderate leader-related effects; see Cox and Weingast 2018). One prominent strand of literature focuses on the (vast) variation in institutional features that autocracies have displayed, historically, and continue to display. Political scientists have put forward several institutional dimensions that are relevant for policy-making in autocracies and have produced numerous regime classifications (e.g., Linz 2000; Geddes 1999; 
Hadenius and Teorell 2007; Geddes et al. 2014). Such distinctions may indirectly matter for development outcomes through incentivizing leaders to select particular policies which, in turn, influence development.

Separating between monarchies, military regimes, one-party and multi-party autocracies, Knutsen and Fjelde (2013) find notable differences in one key determinant of growth, namely the extent of property rights protection. In particular, autocratic monarchies tend to protect property rights well, both when compared to other autocracy types and even when compared to democracies. Similarly, Steinberg et al. (2015) find that monarchies are less likely to experience currency crises than other autocracy types (as well as democracies), suggesting that this is due to the adoption of prudent macroeconomic policies in monarchical regimes. Indeed, when compared to military and personalist autocracies, Wright (2008) finds evidence that, on average, monarchies, but also single-party regimes, have higher growth rates.

Wright (2008) also finds evidence that the presence of a legislature that binds the autocrat carries a positive effect on economic growth as well as capital investment (for similar results pertaining to expropriation risk, see Wright and Wilson 2017). These results are in line with the findings by Gandhi (2008), namely that more "institutionalized" autocracies - where institutionalization captures the presence of parties and legislatures - have higher growth. Focusing more specifically on parties, Bizzarro et al. (2018) find that - also within the subset of autocratic regimes - strong, institutionalized parties are important for explaining differences in growth outcomes. Their argument is that "strong parties establish a relationship of accountability between party leaders and party members, encourage long time horizons, and enhance the party's capacity to solve coordination problems. These features enhance the probability that politicians engage in responsible economic management, provide public goods, and help to ensure political stability. This behavior, in turn, triggers investments and other productivity-enhancing actions by economic actors that enhance economic growth in the short and long term" (p.310).

Other studies focus on how characteristics of state institutions and bureaucracies influence development outcomes, and how they even condition the effect of regime type on development. Knutsen (2013) finds that autocracies have higher growth rates under conditions of high state capacity - and the effect of state capacity on growth is much stronger in autocracies than in democracies -- whereas Hanson (2015) finds the same patterns for human development outcomes pertaining to mortality and education. These authors suggest that state capacity is particularly important for conditioning the effect of authoritarian rule on growth because of the role that rulefollowing and autonomous state agencies play in limiting the discretionary power of autocrats. A 
large case-study oriented literature on developmental states - focusing mainly on authoritarian contexts - have addressed how capable state bureaucracies have helped facilitate creative and effective industrial- and other economic policies that, in turn, spurred economic development (e.g., Amsden 1992; Evans 1995; Wade 1990). A strong regime with a long time horizon and the desire to promote, e.g., export-led industrialization combined with capable state institutions are hypothesized to have allowed, especially, some East and Southeast Asian economies to grow at rapid rates.

However, leaders and institutions are not all there is to autocratic politics, as numerous qualitative historical accounts of political life under such regimes remind us. The people that the leader require support from -- and who typically occupy parliamentary seats and top positions in the party, state administration, or military -- also matter. These people come from distinct social backgrounds and have distinct economic interests, meaning that they likely also have distinct preferences over macroeconomic policies, extent of property rights protection, industrialization, etc. Thus, the identity of the regime's core supporters may affect development.

Several scholars have therefore turned their attention to the role of the "support coalition" (alternatively "winning coalition" or "ruling coalition") for understanding policies and outcomes in autocracies. Albertus and Menaldo (2012) argue that some dictators have strong incentives to expropriate powerful, existing elites once they take office, and redistribute the spoils to the groups that helped launch the new dictator into power. According to Albertus and Menaldo, this strategy enhances the survival of the new dictator, even if such expropriation hurts economic growth.

There may also be other differences among elite support groups (than those pertaining to being supporters of the old vs new regime) that incentivize autocratic regimes to pursue different economic policies. It is plausible to assume that landowners and urban elites have very different preferences when it comes to promoting industrialization, for example, as the former may anticipate that their relative power resources are weakened over time as a consequence of industrialization, whereas the latter may benefit (see, e.g., Ansell and Samuels 2014). This is just one example suggesting that the social identity of the autocratic regime's support coalition may influence economic policy, and thus development.

Bueno de Mesquita et al. (2003) present a fairly parsimonious, but forceful, model focusing on another aspect of what they term the "winning coalition", namely its size. Big coalitions incentivize leaders to maintain support through the provision of policies and public goods that benefit wide segments of the population. Such policies are typically conducive to economic growth. In contrast, leaders relying on narrow coalitions have incentives to focus their spending 
on the distribution of private goods directly to coalition members in order to retain power. Such distributive policies, while beneficial to both the leaders and their few supporters, are typically not conducive to growth. Big coalitions are typically found in democracies. Yet, even for autocratic regimes coalition sizes vary immensely. The argument as well as empirical tests in Bueno de Mesquita et al. (2003) thus suggest that variations in coalition size may contribute to explain the large variation in growth outcomes among autocracies.

Despite the plausibility of the argument made by Bueno de Mesquita and colleagues, however, this latter result cannot yet be considered as established knowledge. In addition to discussing conceptual difficulties with delimiting the size and nature of the winning coalition, especially in autocratic contexts, Gallagher and Hanson (2015) point out that there are quite severe validity problems with the measures that Bueno de Mesquita et al. (2003) use to proxy for coalition size. In the empirical analysis below, I will draw on a new and more direct measure of the size of the regime's support coalition when studying how this feature - together with other political and institutional characteristics reviewed in this section - relate to economic growth in autocratic contexts. First, however, I turn to descriptive analysis that corroborate the notion that there is more variation in growth outcomes in autocracies than in democracies.

\section{Data}

Several plausible hypotheses on what generates variation in economic performance among autocratic regimes have previously been hard to test by using cross-country data. There has been a lack of precise measures that tap into the concepts of theoretical interest and that also have sufficiently long time series and extensive cross-country coverage. There is still a need for more data collection, for instance on the detailed features of autocratic support coalitions. However, recent data collection efforts mean that we are much better equipped to assess different propositions on what generates variations in autocratic economic development outcome today than we were only a few years ago.

Notable in this regard is the Varieties of Democracy (V-Dem) dataset (Coppedge et al. 2018a; Pemstein et al. 2017). V-Dem contains more than 400 indicators, and numerous indices constructed from these indicators, pertaining to democracy and various other aspects of political life. I use data from V-Dem data below in order to identify the sub-set of autocratic regime observations and in order to capture possible explanatory factors behind the variation in growth among autocracies. These factors include legislatures, party institutionalization, state capacity, and 
the size and identity of the regime's support coalition. The V-Dem data cover 201 polities, with the modal time series being 1900-2017. For a subset of up to 91 countries, several indicators are coded back into the $19^{\text {th }}$ century and sometimes all the way back to 1789 , due to the so-called Historical V-Dem data collection (Knutsen et al. 2018).

For many of the analysis below, I draw a crisp distinction between "democracies" and "autocracies", for instance in order to focus on determinants of growth only in the latter sub-set of observations. When doing so, I rely on the Regimes of the World (RoW) measure from Lührman et al. (2018). This measure distinguishes between four categories of regimes by drawing on different V-Dem measures and a select set of rules. The four categories are "Closed autocracy", "Electoral autocracy", "Electoral democracy", and "Liberal democracy". I collapse the two autocracy categories as well as the two democracy categories when constructing the dummy distinguishing autocracies from democracies. The operational threshold that Lührman et al. set for identifying electoral democracies (and hence democracies in my two-category scheme), are that these regimes must score above 2 on V-Dem indicators for multi-party elections as well as free and fair elections, in addition to scoring above 0.5 on the index for electoral democracy called Polyarchy (which ranges from 0 to 1 ; Teorell et al. 2018).

When employing a continuous measure for democracy in the analysis, I use V-Dem's Polyarchy index (Teorell et al. 2018). Polyarchy aims to capture the electoral democracy concept introduced in Dahl (1971) and builds on five sub-indices pertaining to, respectively, whether officials are elected (directly or indirectly), the freeness and fairness of these elections, freedom of speech, freedom of association, and the extension of suffrage in the adult population. For presentational reasons, I will describe the other measures drawn from V-Dem right before they enter the analysis for the first time.

In order to capture the dependent variable (economic growth) and a key control (initial income level), I utilize data from Farris et al. (2017). These data have very extensive time series, which, in combination with the V-Dem data, allows me to extend the analysis back to 1789 . The data are constructed by drawing on several existing GDP and population time series, and are produced by a dynamic latent trait model. This procedure alleviates different types of measurement errors in the extant GDP and population series. Specifically, I will use the point estimates for Ln GDP per capita from Farris et al. that are benchmarked in the long time-series Maddison data. The estimates for GDP per capita growth are also constructed from these estimates for Ln GDP per capita. 


\section{Empirical patterns I: Variation in growth performance for different regimes}

In this section, I re-assess the pattern that autocracies display more variation in economic development performances, focusing on economic growth. I start by considering variation in medium-term growth performances across countries, before assessing cross-country variation in growth performances across a longer time interval. Next, I focus on variation within countries, and test whether autocracies also display more variation over time, also considering whether autocracies are less likely to avoid economic crises.

Figure 1 displays violin-plots detailing the distributions of average annual growth in GDP per capita for autocratic and democratic regimes, as identified from the RoW measure from Lührman et al. (2018), globally. The average annual growth rates are calculated for each decade (one country-decade is an observation), starting in 1790 - regime type is measured in that year and growth is measured across 1790-1799 - and ending in 2000.

The average growth rates are 1.0 percent for autocracies and 2.4 percent for democracies. This is a sizeable difference, although this is not the main point here. The main point is rather that when compared to autocracies, democracies show much less variation. The long whiskers in the violin-plots reveal the several, more extreme observations in autocracies. Sure, democracies seldom observed the very high Chinese-style growth rates of recent years, but they do not observe the extreme growth disasters that are historically fairly common in autocracies either, a few examples being China under Mao’s Great Leap Forward, Zaire under Mobutu, or current Venezuela under Maduro. Also when we disregard the most extreme observations, there is generally more variation in growth outcomes among autocracies than among democracies. Overall, the standard deviation in the autocratic sample is 3.2 , whereas it is 2.1 in the democratic sample. 


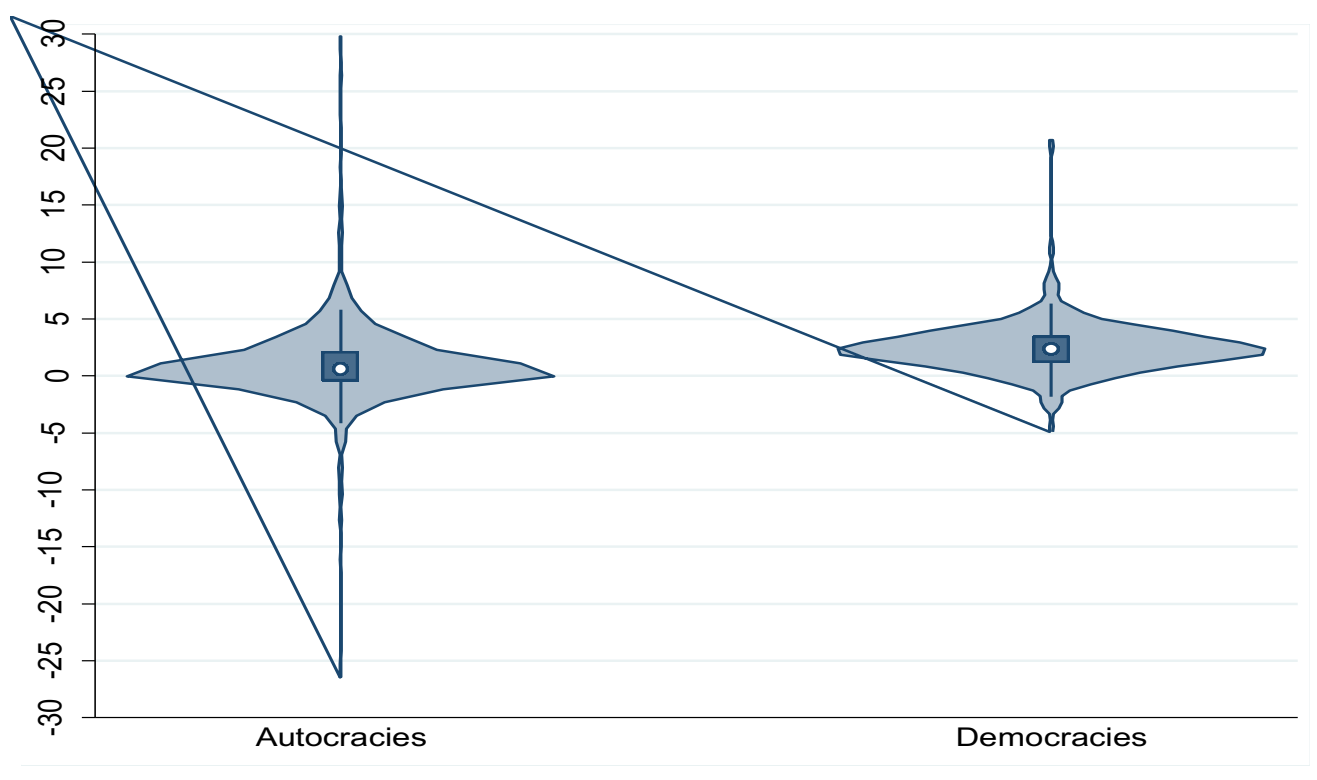

Figure 1: Violin-plots displaying the distributions of annualized GDP per capita growth, with country-decade, as unit of observation for autocracies and democracies.

One may also note that democracies very seldom achieve negative growth rates across the span of a decade. When ranking according to growth performance, the 10th percentile among democratic decades, according to these data, actually had positive growth at +0.1 percent annual GDP per capita growth. The 10th percentile among autocratic decades had -1.6 percent annual growth. At the 5 th percentile, the number is -0.5 percent for democracies and -2.7 percent for autocracies. The latter number implies that 5 percent of all autocracy-decades experienced that the economy was shaved by about $1 / 4$ of its size, or more, after 10 years.

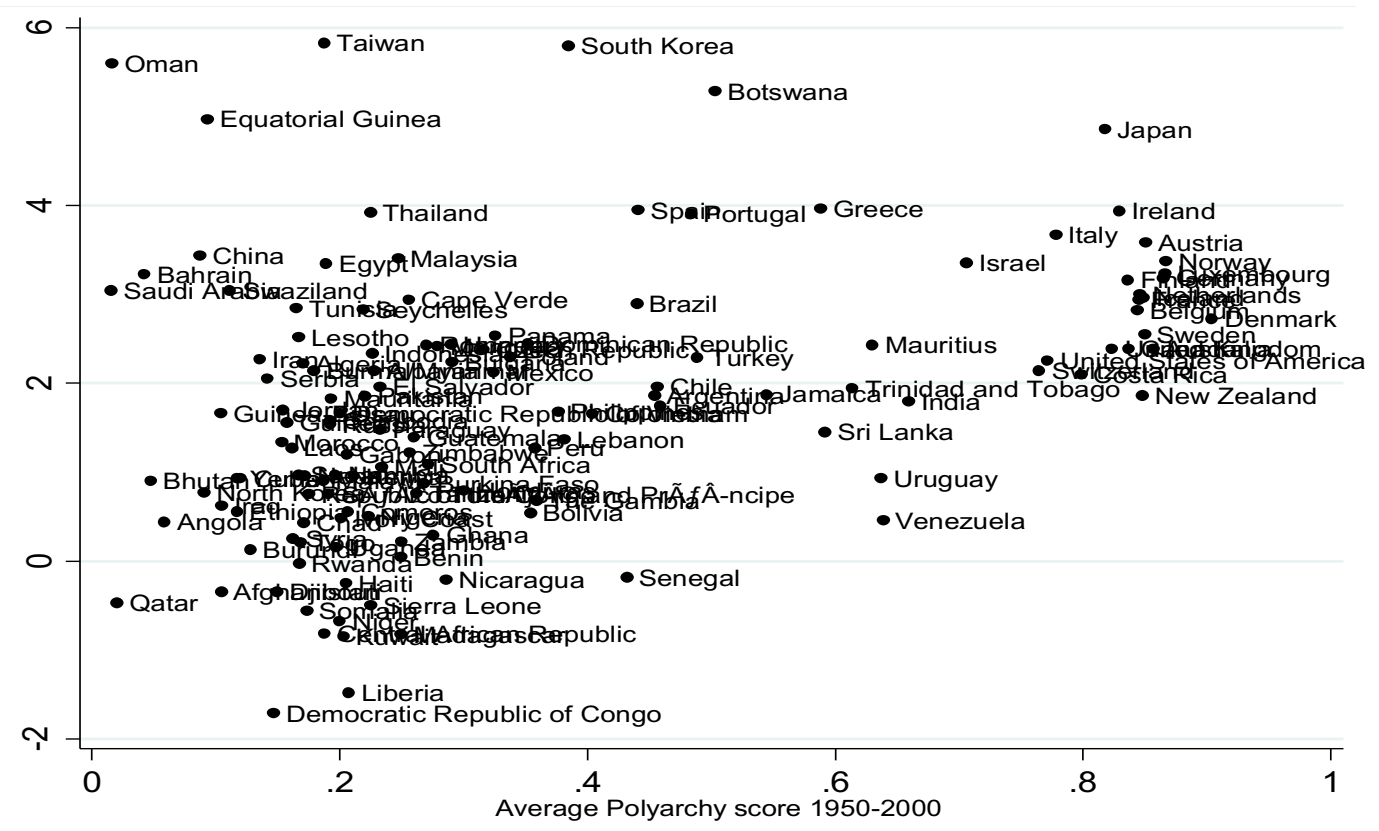

Figure 2: Regime type and growth performance across fifty years (1950-2000). 
The larger variation in growth outcomes among autocracies is also clear when considering a longer period of time. The $\mathrm{x}$-axis of Figure 2 maps average democracy score across 1950-2000 according to Polyarchy. The y-axis displays average annualized growth rate across the same time period.

If we consider the countries with an average score below 0.5 on Polyarchy as relatively autocratic, the range in annualized growth rates within this group across the 50-year span is almost 8 percent, with DR Congo (close to GDP per capita growth rate of -2) and Taiwan (close to +6 ) as the extremes. The range for relatively democratic countries is less than 5 percent, with Venezuela (close to +0.5$)$ and Botswana (about +5 percent) as the extremes. Thus, no relatively democratic country posted negative GDP per capita growth within this time frame, which contrasts with the numerous autocracies that observed shrinking economies. The variation decreases further when we restrict the focus to the most democratic countries; when considering countries that scored above 0.8 , on average, on Polyarchy, annualized growth rates vary between +2 and +5 percent.

Obviously, there are other factors that may generate this correlation between regime type and variance in growth outcomes. For example, autocracies may be more common in decades with higher variance in growth or in particular countries with larger growth variation due to other (e.g., geographical, cultural or political-historical) factors.

To investigate this matter further, while accounting for some of the mentioned sources of bias, the first two columns in Table 2 are OLS fixed effects regressions. The dependent variable is a dummy variable, which takes the value 1 if a country experienced a decline in GDP per capita and 0 if GDP per capita growth was zero or positive. Thus, this may be considered a proxy for a country experiencing an economic crisis. In contrast to in the descriptive analysis, country-year is the unit of analysis, allowing me to pick up also short-term crises. In addition to measures of regime type, the regressions include initial level of Ln GDP per capita (to account for convergence dynamics; see, e.g., Barro and Sala-i-Martin 2004) as well as country- and year fixed effects. The dependent variable is forward-lagged by 5 years in order to reflect the substantial time it likely takes for regime type to transmit an effect on growth (see Papaiouannou and Siorounis 2008; Knutsen 2011c). Standard errors are clustered by country in order to account for panel-level serial correlation.

Model 1 employs the dichotomized democracy-autocracy measure based on the RoW classification. The model draws on a total of 18,288 country-year observations from 184 countries, and 1794 and 2015 are, respectively, the first and last years the dependent variable is measured. The democracy dummy is negative and statistically significant at the 5 percent level. The point 
estimate from this linear probability model suggests that, even when holding income level, country, and year constant, going from democracy to autocracy in year $t$ increases the probability of observing an economic crisis in year $t+5$ by about 0.05 . The baseline risk of observing negative growth in the sample is 0.34 . Model 2 employs the continuous Polyarchy measure instead of the democracy dummy in an otherwise similar model specification. The Polyarchy coefficient is negative, as expected, and even more precisely estimated with a t-value of -2.58 . The point estimate suggests that going from maximum (1) to minimum (0) on Polyarchy in year $t$ increases the probability of observing negative growth in $t+5$ by about 0.13 .

Table 1: Regime type, economic crisis, and variation in growth rates

\begin{tabular}{|c|c|c|c|c|c|c|}
\hline \multirow{5}{*}{$\begin{array}{l}\text { Dependent variable } \\
\text { Specification }\end{array}$} & \multicolumn{6}{|c|}{ Negative growth in } \\
\hline & \multicolumn{2}{|l|}{$t+5$} & \multicolumn{4}{|c|}{ Standard deviation in growth from $t$ to $t+10$} \\
\hline & \multicolumn{2}{|l|}{ OLS FE } & \multicolumn{2}{|l|}{ OLS } & \multicolumn{2}{|l|}{ OLS FE } \\
\hline & $(1)$ & $(2)$ & (3) & (4) & (5) & $(6)$ \\
\hline & $\mathrm{b}(/ \mathrm{t})$ & $\mathrm{b}(/ \mathrm{t})$ & $\mathrm{b}(/ \mathrm{t})$ & $\mathrm{b}(/ \mathrm{t})$ & $\mathrm{b}(/ \mathrm{t})$ & $\mathrm{b}(/ \mathrm{t})$ \\
\hline \multirow[t]{3}{*}{ Democracy (RoW dummy) } & $-0.051 * *$ & & $-0.016^{* *}$ & & -0.008 & \\
\hline & $(-2.115)$ & & $(-2.078)$ & & $(-1.501)$ & \\
\hline & & & & & & - \\
\hline \multirow[t]{2}{*}{ Democracy (Polyarchy) } & & $-0.133^{* *}$ & & $-0.036 * *$ & & $0.030 * * *$ \\
\hline & & $(-2.579)$ & & $(-2.417)$ & & $(-2.696)$ \\
\hline \multirow[t]{2}{*}{ Ln GDP per capita } & $0.116^{* * *}$ & $0.118^{* * *}$ & -0.002 & -0.001 & -0.008 & -0.006 \\
\hline & $(5.588)$ & $(5.964)$ & $(-0.559)$ & $(-0.122)$ & $(-1.344)$ & $(-1.086)$ \\
\hline Year FE & $\mathrm{Y}$ & $\mathrm{Y}$ & $\mathrm{Y}$ & $\mathrm{Y}$ & $\mathrm{Y}$ & $\mathrm{Y}$ \\
\hline Country FE & $\mathrm{Y}$ & $\mathrm{Y}$ & & & $\mathrm{Y}$ & $\mathrm{Y}$ \\
\hline $\mathrm{N}$ & 18288 & 18477 & 17304 & 17486 & 17304 & 17486 \\
\hline Countries & 184 & 184 & 184 & 184 & 184 & 184 \\
\hline Time series DV: & \multicolumn{2}{|l|}{$1794-2015$} & \multicolumn{2}{|c|}{$1790-2015$} & & \\
\hline $\mathrm{R}^{2}$ & 0.126 & 0.126 & 0.065 & 0.068 & 0.042 & 0.043 \\
\hline
\end{tabular}

Notes: ${ }^{*} \mathrm{p}<0.1 ;{ }^{* *} \mathrm{p}<0.05 ;{ }^{* * *} \mathrm{p}<0.01$. Country-year is unit of analysis. All errors are robust and clustered by country. Constant, country dummies and year dummies are omitted from table.

Rather than focusing on the risk of observing negative economic growth, Models 3-6 address the overall variability in growth rates over time. They do so by employing the standard 
deviation in annual growth for a country within a ten-year span as dependent variable. Countryyear remains the unit of analysis, but for each year $t$, for which the covariates are measured, we calculate the standard deviation in growth for the country across $t$ to $t+10$. Again, we maintain the OLS set-up with standard errors clustered by country, year-fixed effects, and a control for initial income level. Models 3 (RoW democracy dummy) and 4 (Polyarchy) omit the country-fixed effects to allow for comparisons across countries, whereas Models 5 (RoW democracy dummy) and 6 (Polyarchy) include the country-fixed effects.

These specifications display a consistent relationship between having (more) autocratic regimes and larger growth volatility - all four democracy coefficients have negative signs. Still, the association between autocracy and growth volatility seems to be driven, in part, by country-specific confounders, as the coefficients in Models 5-6 are attenuated relative to those in Models 3-4. Indeed, when employing the less informative dummy variable, the fixed effects specification (Model 5) shows a negative relationship that is statistically insignificant at conventional levels. Yet, even in this specification, the $\mathrm{t}$-value is -1.5 , and the point estimate suggests that going from autocracy to democracy reduces growth volatility by about the same amount as a one-point increase on the natural logarithmic scale for GDP per capita - equivalent, for example, to the difference between a GDP per capita of 1500 and 4000 USD. When we allow for cross-country comparisons or when we employ the finer-grained Polyarchy measure, the relationship between regime type and growth volatility is statistically significant at least at the five percent level. Although the result is not entirely robust, there is thus fairly strong evidence that autocracy is related to higher variation in growth rates.

\section{Empirical patterns II: The institutional and other correlates of growth in autocracies}

Having (re-)established the large variation in growth performances among autocratic regimes, I now turn to analyzing factors that may plausible generate this variation. More specifically, I return to the extant explanations of variation in growth among autocracies pertaining to institutional-and support group features reviewed in Section II, and investigate empirically how they relate to GDP per capita growth. Once again, I draw on the V-Dem and Farris data, in order to cover a large number of polities and the bulk of modern history. 
I run regression models on all autocratic regimes, as operationalized by the RoW measure. Once again, I employ a sparse OLS specification, controlling for initial income level (Ln GDP per capita) and country- and year-fixed effects. Country-year is unit of analysis, errors are clustered by country, and the dependent variable is GDP per capita growth measured in year $t+5$ (covariates are measured in $t$ ). I employ the following institutional measures:

First, given the focus on regime types in the autocratic politics literature, I draw on a recent dataset from Anckar and Fredriksson (2018). The measures contained in this dataset build on the regime categorization by Geddes et al. (2014), but extends the coding all the way back to 1800 and adds categories that are particularly relevant for the $19^{\text {th }}$ century (such as oligarchic regimes of different kinds). I construct four dummies from Anckar and Fredriksson's narrow categorization, capturing, respectively, single-party regimes, personalist regimes, military regimes and monarchies (collapsing all monarchy categories provided by the authors). The reference category is thus a mix of other autocracy types, notably including multi-party autocracies and oligarchies.

Second, I use two V-Dem measures pertaining to legislatures. The first is simply a dummy capturing the existence of a legislature, following V-Dem's v2lgbicam indicator. Next, I extend VDem's Legislative Constraints on the Executive index (v2xlg_legcon), which originally extends from 0-1 for countries with legislatures, by assigning 0 -scores to all countries without legislatures. This index builds on four separate indicators and aims to capture the extent to which the legislature and other government agencies are capable of questioning, investigating, and overseeing the executive.

Third, I employ V-Dem's Party Institutionalization index (v2xps_party), which extends from $0-1$. This index aims to capture "various attributes of the political parties in a country, e.g., level and depth of organization, links to civil society, cadres of party activists, party supporters within the electorate, coherence of party platforms and ideologies, party-line voting among representatives within the legislature" (Coppedge 2018b: 240). While pertaining to the partysystem level, this index places more weight on larger parties, and in single-party systems the index thus captures features of the ruling party. This index typically has shorter time series than many of the other V-Dem measures (that extend back to 1789), simply because political parties were not a feature of many polities before the late $19^{\text {th }}$ or even $20^{\text {th }}$ centuries.

Fourth, I employ V-Dem's indicator for a rule-following and impartial state administration $(v 2 c \operatorname{lrsp}(t)$, which may be considered as a proxy for state capacity. Impartiality and governing according to rules is one critical aspect of a Weberian bureaucracy, which is widely presumed to correlate positively with the capacity of state institutions. This indicator is based on the following question: "Are public officials rigorous and impartial in the performance of their duties?" 
(Coppedge 2018b: 157), with lack of respect for the law or arbitrary and biased administration giving low scores.

Fifth, I go beyond institutional features and test measures of the size and identity of the regime's support coalition. The relevant measures are from Historical V-Dem (Knutsen et al. 2018), and since they are not (yet) coded by “contemporary" V-Dem, the longest time series extend “only" from 1789-1920, and close to 70 countries are covered. The support coalition size measure asks about the share of the adult population that belong to the regime's support groups - i.e., groups that are "supportive of the regime, and, if it/they were to retract support would substantially increase the chance that the regime would lose power" (Coppedge et al. 2018b: 214). This measure is attuned to distinguishing between the sizes of such coalitions in autocracies. ${ }^{2}$

I also employ the support group identity (v3regsupgroups) coding from Historical V-Dem to code the social profiles of regimes' support coalitions. More specifically, following the discussion above on the potential relevance of agrarian and rural-based versus urban-based support coalitions, I construct two dummies to capture whether a regime's support coalition include substantial elements from these strata. I note that the two dummies do not constitute a mutually exclusive categorization scheme; regimes that have substantial portions of their support coalitions made up both by rural and urban groups may score 1 on both dummies. Specifically, the urban support group dummy is scored 1 if one or more of the following groups are substantially represented in the coalition (score $>1$ on the original measures for these sub-groups from V-Dem): Business elites, Urban working classes, Urban middle classes. The rural support group dummy is similarly constructed, but pertains to the following sub-groups: Agrarian elites, Rural working classes, Rural middle classes.

Model 1, Table 1 includes the four regime dummies from Anckar and Fredriksson in addition to the controls, drawing on 10,480 autocratic country-years from 163 countries. The longest time series cover 210 years. The results from this model suggest heterogeneity in growth rates between the regime types. The highest point estimate is obtained for single-party regimes, although such regimes do not have (statistically) significantly higher growth than the reference category (which comprises, e.g., multi-party autocracies and oligarchies). Still, single-party regimes do have significantly higher growth rates than both personalist regimes and monarchies, and the

\footnotetext{
2 The lowest category presented to coders is "Extremely small (About 1 percent of the population or less; examples of this could include regimes supported by — and needing the support from — a handful of higher-rank military officers, or by only a royal council and a few hundred landowners)" (Coppedge et al. 2018b: 215). The highest category is "Large (More than 30 percent; examples of this could include regimes supported by — and needing the support from - large ethnic groups (and then not only the elites/leaders of such groups), or by rural working classes in rural societies.)".
} 
point estimates suggest that going from a monarchical- to a single-party regime increases annual GDP per capita growth by about 1.2 percentage points. In other words, while extant work focusing on data from the most recent decades - have found that monarchies are better at protecting property rights and avoiding currency crises than other autocracy types, these results suggest that they are not better at enhancing economic growth, rather to the contrary. Note, however, that with the extension of the time series back to 1800 , I here capture a much larger number of regimes, in particular monarchies, than the reviewed, extant studies that only cover the most recent decades. Perhaps less surprising, personalist regimes also perform worse in terms of growth than single-party regimes (and "other" autocracies), corroborating a notion that is present, e.g., in the large case-based literature on personalist regimes and their poor economic track-records in Sub-Saharan Africa (see, e.g., Meredith 2013).

Model 2 focuses on legislatures, adding the dummy for legislature existence as well as the index capturing legislative constraints on the executive. The model includes 14,402 autocratic country-year observations, with some time series extending across 221 years. Interestingly, the legislature dummy is positive with a t-value of 1.8, whereas the legislative constraints index is negative with a t-value of -1.7 . While only weakly significant, the latter result contrasts with a widespread notion from the literature that legislative constraints on autocrats are key for ensuring economic development (e.g., North and Weingast 1989; Cox and Weingast 2018). It also goes against the results reported by Wright (2008) - using different proxies for what constitutes a constraining legislature and far shorter time series - that binding legislatures enhance growth, whereas non-binding legislatures do not.

Model 3 draws on 9635 observations and includes the Party Institutionalization index as its core independent variable. As discussed, Bizzarro et al. (2018) find a strong, positive effect of a very similar measure of "Party strength" on growth, and report that this effect is robust when only investigating sub-sets of autocratic countries with time series starting in 1900. Model 3 employs time series extending back into the $19^{\text {th }}$ century, but corroborates the finding in Bizzarro et al. (2018). The point estimate predicts that a change from a minimum (0) to maximum (1) on the Party Institutionalization index raises annual GDP per capita growth by 1.8 percentage points. This relationship is statistically significant at the 5 percent level. 
Table 2: Institutions, support groups and growth in autocracies. OLS FE regressions with GDP per capita growth in year $t+5$ as dependent variable

\begin{tabular}{|c|c|c|c|c|c|c|c|c|}
\hline & $\begin{array}{l}1 \\
\mathrm{~b}(/ \mathrm{t})\end{array}$ & $\begin{array}{l}2 \\
\mathrm{~b}(/ \mathrm{t})\end{array}$ & $\begin{array}{l}3 \\
b(/ t)\end{array}$ & $\begin{array}{l}4 \\
b(/ t)\end{array}$ & $\begin{array}{l}5 \\
\mathrm{~b}(/ \mathrm{t})\end{array}$ & $\begin{array}{l}6 \\
b(/ t)\end{array}$ & $\begin{array}{l}7 \\
\mathrm{~b}(/ \mathrm{t})\end{array}$ & $\begin{array}{l}8 \\
b(/ t)\end{array}$ \\
\hline \multirow[t]{2}{*}{ Single-party reg. } & 0.430 & & & & 0.279 & & & \\
\hline & $(1.175)$ & & & & $(0.623)$ & & & \\
\hline \multirow[t]{2}{*}{ Personalist reg. } & $-0.626^{*}$ & & & & $-0.901 * *$ & & & \\
\hline & $(-1.881)$ & & & & $(-2.499)$ & & & \\
\hline \multirow[t]{2}{*}{ Military reg. } & 0.004 & & & & 0.142 & & & \\
\hline & $(0.014)$ & & & & $(0.400)$ & & & \\
\hline \multirow[t]{2}{*}{ Monarchy } & $-0.732^{* *}$ & & & & $-0.943^{*}$ & & & \\
\hline & $(-2.124)$ & & & & $(-1.887)$ & & & \\
\hline \multirow[t]{2}{*}{ Legislature } & & $0.516^{*}$ & & & $0.798^{*}$ & & & \\
\hline & & $(1.809)$ & & & $(1.964)$ & & & \\
\hline \multirow[t]{2}{*}{ Leg. Constr. } & & $-0.870^{*}$ & & & $-1.720^{* *}$ & & & \\
\hline & & $(-1.666)$ & & & $(-2.364)$ & & & \\
\hline \multirow[t]{2}{*}{ Party instit. } & & & $1.772^{* *}$ & & $1.476^{*}$ & & & \\
\hline & & & $(2.270)$ & & $(1.855)$ & & & \\
\hline \multirow[t]{2}{*}{ Impartial adm. } & & & & 0.136 & $0.361^{* *}$ & & & \\
\hline & & & & $(1.335)$ & $(2.270)$ & & & \\
\hline \multirow[t]{2}{*}{ Sup. group size } & & & & & & -0.011 & & -0.075 \\
\hline & & & & & & $(-0.104)$ & & $(-0.591)$ \\
\hline \multirow[t]{2}{*}{ Rural sup.gr. } & & & & & & & 0.194 & 0.089 \\
\hline & & & & & & & $(0.698)$ & $(0.314)$ \\
\hline \multirow[t]{2}{*}{ Urban sup. gr. } & & & & & & & 0.215 & 0.214 \\
\hline & & & & & & & $(0.734)$ & $(0.732)$ \\
\hline \multirow[t]{2}{*}{ Ln GDP p.c. } & $-1.144 * * *$ & $-0.963 * * *$ & $-1.626^{* * *}$ & $-0.970^{* * *}$ & $-1.803^{* * *}$ & -0.444 & -0.570 & -0.497 \\
\hline & $(-4.319)$ & $(-3.874)$ & $(-4.993)$ & $(-3.896)$ & $(-5.181)$ & $(-1.297)$ & $(-1.361)$ & $(-1.209)$ \\
\hline Country-FE & $\mathrm{Y}$ & $\mathrm{Y}$ & $\mathrm{Y}$ & $\mathrm{Y}$ & $\mathrm{Y}$ & $\mathrm{Y}$ & $\mathrm{Y}$ & $\mathrm{Y}$ \\
\hline Year-FE & $\mathrm{Y}$ & $\mathrm{Y}$ & $\mathrm{Y}$ & $\mathrm{Y}$ & $\mathrm{Y}$ & $\mathrm{Y}$ & $\mathrm{Y}$ & $\mathrm{Y}$ \\
\hline $\mathrm{N}$ & 10480 & 14402 & 9635 & 14466 & 8146 & 5546 & 5256 & 5061 \\
\hline Countries & 163 & 181 & 177 & 181 & 161 & 67 & 66 & 64 \\
\hline Max years & 210 & 221 & 169 & 221 & 169 & 133 & 133 & 133 \\
\hline $\mathrm{R}^{2}$ & 0.085 & 0.029 & 0.037 & 0.028 & 0.090 & 0.061 & 0.064 & 0.064 \\
\hline
\end{tabular}

Notes: ${ }^{*} \mathrm{p}<0.1 ; * * \mathrm{p}<0.05 ;{ }^{* * *} \mathrm{p}<0.01$. The analysis is restricted to countries scored as autocracies by the RoW measure from Lührman et al. (2018). Country-year is unit of analysis. All errors are robust and clustered by country. Constant, country dummies and year dummies are omitted from the table.

Model 4 includes the impartial and rule-following administration measure. As expected from the literature on the importance of capable and rule-following state administrations in "developmentalist regimes" cited above, the point estimate is positive. Yet, the coefficient fails conventional levels of statistical significance 
Still, it may be problematic to meaningfully interpret the coefficients from Models 1-4 given the correlation between various institutional features; single-party regimes are for example likely to score higher in terms of party institutionalization and have legislatures. In order to gauge the "direct relationship" between the different institutional features and growth, I thus enter all the institutional measures simultaneously into Model 5. Note, however, that the sample is truncated in the extensive specification due to listwise deletion (8146 observations). Further, this extensive specification risks introducing post-treatment bias. For instance, if legislative constraints lead to more impartial bureaucracies, we may be controlling for a key indirect of legislative constraints on growth.

Yet, most results do not change very much from Models 1-4 to Model 5. Notably, personalist regimes and monarchies have significantly lower growth than single-party (and "other") autocracies, the presence of a legislature enhances growth, but stronger legislative constraints relate negatively growth, and higher party institutionalization is conducive to growth. The only major change pertains to the impartial and rule-following administration variable, which increases almost three-fold in size and now turns statistically significant at the 5 percent level. ${ }^{3}$

When considering the support coalition features from the shorter (1789-1920) Historical V-Dem time series, there are no clear relationships with growth. This is the case both in models considering support group size (Model 6) and identity (Model 7) separately, or when these variables are entered jointly (Model 8). In other words, these analyses - which employ more direct measures of coalition size than those employed by Bueno de Mesquita et al. (2003) and draw on more than 5000 historical country-year observations - do not corroborate the notion that large-coalition autocracies are more conducive to growth than small-coalition ones. Another notable null-result is that having urban support groups do not clearly correlate with subsequent GDP per capita growth, and neither does having rural groups in the support coalition.

\footnotetext{
${ }^{3}$ Further analysis (not displayed) suggest that about half of this change in the coefficient size is due to the change in sample from the parsimonious Model 4 to the extensive Model 5. When Model 4 is re-run on the 8146 observations from Model 5, the impartial administration coefficient is .25 with a t-value of 1.6.
} 


\section{Conclusion}

In this paper, I have reviewed different studies pertaining to the empirical pattern that autocratic regimes display vast variation - and, indeed, much so than democracies - in economic development outcomes. I have discussed some plausible explanations of this pattern, highlighting studies that point to features of the leader, institutions in autocracies, or the nature of the regime's support coalition. Thereafter, I presented descriptive patterns and tests that illustrate the wide variation in economic growth in autocratic regimes. Variation in growth outcomes - both in the shorter and longer term, and both across and within countries - is larger among autocracies than among democracies. As such, democracy seems to act as a "safety-net" that guards against the worst economic development outcomes.

Finally, I presented analysis pertaining to plausible explanations of why some autocratic regimes have higher economic growth than others, assessing a variety of institutions and support group features. This exercise suggests that single-party autocracies have higher growth rates than personalist regimes and monarchies, even when accounting for initial income and country- and year-fixed effects. Further, higher degrees of party institutionalization correlate positively with growth in autocracies. The exercise also yields a series of negative and null results that are surprising in light of extant theoretical contributions and empirical studies using cruder proxies and shorter time series. Notably, I do not find support for the notion that stronger legislative constraints on autocrats enhance growth, rather to the contrary, and there is no correlation between the size of an autocratic regime's support coalition and growth.

While these results rely on extensive data material - with far longer time series than those used in most earlier studies - I highlight that none of the results reported in this paper should be regarded as conclusive. Particular measurement errors, alternative confounders, or reverse causality may influence some of the reported results. Such alternative, methodological explanations of the reported relationships deserve closer scrutiny. Thus, the results reported here should only be regarded as a point of departure for future studies on how institutions and support group features influence economic development outcomes in autocracies. 


\section{References}

Acemoglu, Daron, Simon Johnson, and James A. Robinson. 2001. The colonial origins of comparative development. American Economic Review 91(5):1369-1401.

Acemoglu, Daron, Suresh Naidu, Pascual Restrepo and James A. Robinson. 2018. Democracy does cause growth. Journal of Political Economy (forthcoming).

Albertus, Michael and Victor Menaldo. 2012. If You're Against Them You're With Us. Comparative Political Studies 45(8): 973-1003.

Amsden, Alice H. 1992. Asia's Next Giant: South Korea and Late Industrialization. New York: Oxford University Press.

Anckar, Carsten and Cecilia Fredriksson. 2018. Classifying political regimes 1800-2016: A typology and a new dataset. European Political Science Online First.

Ansell, Ben W and David J Samuels. 2014. Inequality and Democratization. Cambridge: Cambridge University Press.

Barro, Robert J. and Xavier Sala-i-Martin. 2004. Economic Growth. Cambridge, MA.: MIT Press.

Boix, Carles, Michael Miller, and Sebastian Rosato. 2013. A Complete Dataset of Political Regimes, 1800-2007. Comparative Political Studies 46(12)1523-54.

Besley, Timothy and Masayuki Kudamatsu. 2007. "Making Autocracy Work." London: LSE, STICERD - Development Economics Paper No 48. Working Paper.

Bizzarro, Fernando, John Gerring, Carl Henrik Knutsen, Allen Hicken, Michael Bernhard, SvendErik Skaaning, Michael Coppedge and Staffan I. Lindberg. 2018. Party Strength and Economic Growth. World Politics 70(2): 275-320.

Bueno de Mesquita, Bruce, Alastair Smith, James D. Morrow and Randolph M. Siverson. 2003. The logic of political survival. MIT press.

Clark, Gregory. 2007 A Farewell to Alms: A Brief Economic History of the World. Princeton: Princeton University Press.

Clark, William R., Matt Golder and Sona N. Golder. 2013. Principles of Comparative Politics, $2^{\text {nd }}$ ed. Thousand Oaks, CA. CQ Press. 
Coppedge, Michael, John Gerring, Carl Henrik Knutsen, Staffan I. Lindberg, Svend-Erik Skaaning, Jan Teorell, David Altman, Michael Bernhard, M. Steven Fish, Agnes Cornell, Sirianne Dahlum, Haakon Gjerløw, Adam Glynn, Allen Hicken, Joshua Krusell, Anna Lührmann, Kyle L. Marquardt, Kelly McMann, Valeriya Mechkova, Juraj Medzihorsky, Moa Olin, Pamela Paxton, Daniel Pemstein, Josefine Pernes, Johannes von Römer, Brigitte Seim, Rachel Sigman, Jeffrey Staton, Natalia Stepanova, Aksel Sundström, Eitan Tzelgov, Yi-ting Wang, Tore Wig, Steven Wilson, and Daniel Ziblatt. 2018a. V-Dem Dataset v8.

Coppedge, Michael, John Gerring, Carl Henrik Knutsen, Staffan I. Lindberg, Svend-Erik Skaaning, Jan Teorell, David Altman, Michael Bernhard, Agnes Cornell, M. Steven Fish, Haakon Gjerløw, Adam Glynn, Allen Hicken, Joshua Krusell, Anna Lührmann, Kyle L. Marquardt, Kelly McMann, Valeriya Mechkova, Moa Olin, Pamela Paxton, Daniel Pemstein, Brigitte Seim, Rachel Sigman, Jeffrey Staton, Aksel Sundtröm, Eitan Tzelgov, Luca Uberti, Yi-ting Wang, Tore Wig, and Daniel Ziblatt. 2018b. V-Dem Codebook v8.

Cox, Gary W. and Barry R. Weingast. 2018. Executive Constraint, Political Stability, and Economic Growth. Comparative Political Studies 51(3): 279-303.

Dahl, Robert. 1971. Polyarchy. New Haven, CT: Yale University Press.

Dahlum, Sirianne and Carl Henrik Knutsen. 2017. Do Democracies Provide Better Education? Revisiting the Democracy-Human Capital Link. World Development 94(1): 186-199.

Doucouliagos, Hristos, and Mehmet Ulubasoglu. 2008. Democracy and Economic Growth: A Meta-Analysis. American Journal of Political Science 52(1):61-83.

Engerman, Stanley L. and Kenneth L. Sokoloff. 2002. Factor Endowments, Inequality, and Paths of Development Among New World Economies. NBER Working Paper no. 9259.

Evans, Peter B. 1995. Embedded Autonomy. States and Industrial Transformation. Princeton: Princeton University Press.

Fariss, Christopher J., Charles D. Crabtree, Therese Anders, Zachary M. Jones, Fridolin J. Linder and Jonathan N. Markowitz. 2017. "Latent Estimation of GDP, GDP per capita, and Population from Historic and Contemporary Sources." Working paper.

Faust, Jörg. 2007. Democracy's Dividend: Political Order and Economic Productivity. World Political Science Review 3(2)1-26. 
Fukuyama, Francis. 2005. State-Building: Governance and World Order in the Twenty-First Century. London: Profile Books.

Fukuyama, Francis 2014. Political Order and Political Decay: From the Industrial Revolution to the Globalisation of Democracy. Profiles Books.

Gallagher, Mary E. and Jonathan K. Hanson 2015. Power Tool or Dull Blade? Selectorate Theory for Autocracies. Annual Review of Political Science 18:367-385

Gandhi, Jennifer. 2008. Dictatorial Institutions and their Impact on Economic Growth. European Journal of Sociology 49(3):3-30.

Gallup, John Luke, Jeffrey D. Sachs and Andrew D. Melinger. 1999. Geography and Economic Development. International Regional Science Review 22(2): 179-232.

Geddes, Barbara. 1999. What Do We Know About Democratization After Twenty Years? Annual Review of Political Science 2:115-144.

Geddes, Barbara, Joseph Wright, and Erica Frantz. 2014. Autocratic Breakdown and Regime Transitions: A New Data Set. Perspectives on Politics 12(2):313-331.

Gerring, John, Philip Bond, William T. Barndt and Carola Moreno. 2005. "Democracy and economic growth: A historical perspective." World Politics 57(3):323-364.

Gerring, John, Strom C. Thanker and Rodrigo Alfaro. 2012. Democracy and Human Development. Journal of Politics 74(1):1-17.

Hadenius, Axel and Jan Teorell. 2007. Pathways from Authoritarianism. Journal of Democracy 18(1):143-156.

Hanson, Jonathan K. 2015. Democracy and State Capacity: Complements or Substitutes? Studies in Comparative International Development 50(3):304-330.

Hall, R and C. Jones. 1999. Why do some countries produce so much more output per worker than others. Quarterly Journal of Economics 114(1):83-116.

Halperin, Morton H., Joseph T Siegle and Michael M. Weinstein. 2005. The Democracy Advantage: How Democracies Promote Prosperity and Peace. New York: Routledge.

Hanson, Jonathan K. 2015. Democracy and State Capacity: Complements or Substitutes? Studies in Comparative International Development 50(3):304-330. 
Jones, Benjamin F. and Benjamin A. Olken. 2005. Do Leaders Matter? National Leadership and Growth since World War II. Quarterly Journal of Economics 120(3):835-864.

Knack, Steven and Philip Keefer. 1995. Institutions and Economic Performance: Cross-Country Tests Using Alternative Measures. Economics \& Politics 7(3):207-227.

Knutsen, Carl Henrik 2011. Democracy, Dictatorship and Protection of Property Rights. Journal of Development Studies 47(1): 164-182.

Knutsen, Carl Henrik. 2011b. Which Democracies Prosper? Electoral Rules, Form of Government and Economic Growth. Electoral Studies 30(1):83-90.

Knutsen, Carl Henrik. 2011c. The Economic Effects of Democracy and Dictatorship. Oslo: University of Oslo. Phd Thesis.

Knutsen, Carl Henrik 2012. Democracy and Economic Growth: A Review of Arguments and Results. International Area Studies Review 15(4): 393-415.

Knutsen, Carl Henrik 2013. Democracy, State Capacity and Economic Growth. World Development 43:1-18

Knutsen, Carl Henrik. 2015. Why Democracies Outgrow Autocracies in the Long Run: Civil Liberties, Information Flows, and Technological Change. Kyklos 68(3):357-84.

Knutsen, Carl Henrik and Hanne Fjelde 2013. Property Rights in Dictatorships: Kings Protect Property Better than Generals or Party Bosses. Contemporary Politics 19(1):94-114

Knutsen, Carl Henrik, Jan Teorell, Tore Wig, Agnes Cornell, John Gerring, Haakon Gjerløw, Svend-Erik Skaaning, Daniel Ziblatt, Kyle Marquardt, Daniel Pemstein and Brigitte Seim. 2018. Introducing the Historical Varieties of Democracy Dataset: Patterns and Determinants of Democratization in the Long 19th Century. Journal of Peace Research Forthcoming.

Lake, David A. and Matthew A. Baum. 2001. The Invisible Hand of Democracy: Political Control and the Provision of Public Services. Comparative Political Studies 34(6):587-621.

Landes, David S. 1998. The Wealth and Poverty of Nations. London: Abacus.

Linz, Juan J. 2000. Totalitarian and Authoritarian Regimes. Boulder, CO.: Lynne Rienner. 
Lührman, Anna, Marcus Tannenberg and Staffan I. Lindberg. 2018. Regimes of the World (RoW): Opening New Avenues for the Comparative Study of Political Regimes. Politics and Governance 6(1):60-77.

Martinez, Luis R. 2018. How Much Should We Trust the Dictator's GDP Estimates? University of Chicago: Working Paper. https://ostromworkshop.indiana.edu/pdf/piep2018/martinez-paper.pdf

Meredith, Martin. 2013. The State of Africa: A History of the Continent Since Independence. London: Simon \& Schuster.

Norris, Pippa. 2012. Making Democratic Governance Work: How Regimes Shape Prosperity, Welfare, and Peace. Cambridge: Cambridge University Press.

North, Douglass C. 1990. Institutions, Institutional Change and Economic Performance. Cambridge: Cambridge University Press.

North, Douglass C. and Barry R. Weingast. 1989. Constitutions and Commitment: The Institutions Governing Public Choice in Seventeenth Century England. Journal of Economic History 44(4):803-832.

Olson, Mancur. 1993. Democracy, Dictatorship and Development. American Political Science Review 87(3):567-576.

Papaioannou, Elias and Gregorios Siourounis. 2008. Democratization and Growth. Economic Journal 118(532):1520-1551.

Pemstein, Daniel, Kyle L. Marquardt, Eitan Tzelgov, Yi-ting Wang, Joshua Krusell and Farhad Miri. 2017. The V-Dem Measurement Model: Latent Variable Analysis for Cross-National and Cross-Temporal Expert-Coded Data. Varieties of Democracy Institute: Working Paper No. 21.

Persson, Torsten and Guido Tabellini. 2006. Democracy and Development: The Devil in the Details. American Economic Review 96(2):319-324.

Pomeranz, Kenneth. 2000. The Great Divergence: China, Europe and the Making of the Modern World Economy. Princeton: Princeton University Press.

Przeworski, Adam and Fernando Limongi. 1993. Political Regimes and Economic Growth. Journal of Economic Perspectives 7(3):51-69. 
Przeworski, Adam, Michael E. Alvarez, Jose Antonio Cheibub, Fernando Limongi. 2000. Democracy and development: Political institutions and well-being in the world, 1950-1990. Cambridge: Cambridge University Press.

Rodrik, Dani .2000. Institutions for high-quality growth: What they are and how to acquire them. Studies in Comparative International Development 35(3):3-31.

Rodrik, Dani. 2008. One Economics, Many Recipes: Globalization, Institutions, and Economic Growth. Princeton: Princeton University Press.

Steinberg, David A., Karrie J. Koesel and Nicolas W. Thompson. 2015. Political Regimes and Currency Crises. Economics \& Politics 27(3):337-361.

Teorell, Jan, Michael Coppedge, Svend-Erik Skaaning, and Staffan I. Lindberg. 2018. Measuring Polyarchy across the Globe, 1900-2017. Studies in Comparative International Development, 2018. OnlineFirst.

Wade, Robert. 1990. Governing the Market: Economic Theory and the Role of Government in East Asian Industrialization. Princeton University Press: Princeton.

Wintrobe, Ronald. 1998. The Political Economy of Dictatorship. Cambridge: Cambridge University Press.

Wright, Joseph. 2008. Do Authoritarian Institutions Constrain? How Legislatures Affect Economic Growth and Investment. American Journal of Political Science 52(2):322-343.

Wilson, Matthew C. and Joseph Wright. 2017. Autocratic Legislatures and Expropriation Risk. British Journal of Political Science 47(1):1-17. 